\title{
Genetic Variants of Thymic Stromal Lymphopoietin in Nonsteroidal Anti-Inflammatory Drug-Induced Urticaria/ Angioedema
}

\author{
María del Carmen Plaza-Serón ${ }^{a} \quad$ Natalia Blanca-López ${ }^{a} \quad$ Natalia Pérez-Sánchez ${ }^{c}$ \\ Inmaculada Doñac Marialbert Acosta-Herrera ${ }^{c}$ María Pino-Yanes ${ }^{b, f}$ \\ Carlos Flores $^{b, f}$ José Antonio Cornejo-Garcíac, d James R. Perkins ${ }^{d}$ \\ Ana Molinad $^{d}$ Maria José Torres ${ }^{c}$ Miguel Blanca ${ }^{c}$ María Gabriela Canto ${ }^{a}$ \\ Pedro Ayuso a, g

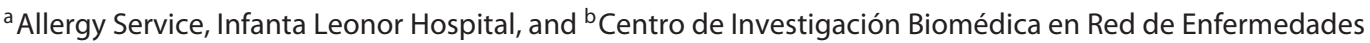
Respiratorias (CIBERES), Instituto de Salud Carlos III, Madrid, ' Allergy Unit, IBIMA, Regional University Hospital of Malaga, UMA, and ${ }^{\mathrm{d}}$ Research Laboratory, IBIMA, Malaga Regional University Hospital, UMA, Malaga, ${ }^{e}$ Research Unit, Multidisciplinary Organ Dysfunction Evaluation Research Network, Dr. Negrin Universitary Hospital, Las Palmas de Gran Canaria, and ${ }^{\mathrm{f}}$ Research Unit, Hospital Universitario Nuestra Señora de Candelaria, Santa Cruz de Tenerife, Spain; 9 INSERM U-954, University of Lorraine and University Hospital Center (CHU) of Nancy, Nancy, France
\end{abstract}

\section{Key Words}

Nonsteroidal anti-inflammatory drugs - Thymic stromal lymphopoietin - Interleukin-7 receptor $\cdot$ TSLP receptor . Imputation

\begin{abstract}
Background: Nonsteroidal anti-inflammatory drugs (NSAIDs) are the most frequent agents involved in hypersensitivity drug reactions, with NSAID-induced urticaria and/or angioedema (NIUA) being the most common entity. Mast cells are key players in NIUA and are activated by thymic stromal lymphopoietin (TSLP). This cytokine functions through recognition by its receptor, composed of IL7Ra (interleukin-7 receptor alpha) and TSLPR (TSLP receptor). These genes have been previously associated with other inflammatory diseases. Methods: We assessed the genetic association between sin-
\end{abstract}

gle nucleotide polymorphisms (SNPs) in TSLP, IL7R and TSLPR and NIUA in Spanish individuals, using genotyped and imputed data. A total of 369 unrelated NIUA patients and 580 NSAID-tolerant control subjects were included, and 6 SNPs in $T S L P, 6$ in IL7R and 3 in TSLPR were genotyped. Further variants were imputed using Mach and the 1,000 Genomes Project (Phase 3) data. Association testing and statistical analyses were performed with Mach2dat and R. Results: A total of 139 SNPs were tested for association following quality control. Two SNPs in TSLP (rs1816678 and rs764917) showed a nominal association ( $p=0.033$ and 0.024 , respectively) with NIUA, although these results were not statistically significant after correcting for multiple comparisons. Conclusions: Although $T S L P, I L 7 R$ and TSLPR are important genes involved in the development of the inflammatory response, we found no significant genetic association with NIUA in our population for common SNPs in these genes.

(c) 2016 S. Karger AG, Basel

\section{KARGER}

E-Mail karger@karger.com

www.karger.com/iaa
(C) 2016 S. Karger AG, Basel

$1018-2438 / 16 / 1694-0249 \$ 39.50 / 0$
Correspondence to: Dr. Miguel Blanca

Allergy Unit, IBIMA, Regional University Hospital of Malaga

Plaza Hospital Civil $\mathrm{s} / \mathrm{n}$

ES-29009 Malaga (Spain)

E-Mail mblancago@gmail.com 


\section{Introduction}

The prevalence of hypersensitivity drug reactions (HDRs) is increasing, and nonsteroidal anti-inflammatory drugs (NSAIDs) are now the most common culprits [1]. The most frequently induced clinical entity in NSAID HDRs is NSAID-induced urticaria and/or angioedema (NIUA) [1], the mechanism of which is thought to be related to cyclooxygenase-1 inhibition in susceptible individuals $[2,3]$. This mechanism has also been suggested for aspirin-intolerant chronic urticaria [4].

Thymic stromal lymphopoietin (TSLP), a cytokine produced by epithelial cells, can initiate and maintain the inflammatory response $[5,6]$ and has been shown to be overexpressed in the affected skin of patients with cutaneous diseases $[7,8]$. Several candidate gene association studies have assessed the importance of TSLP in NSAIDexacerbated respiratory disease (NERD) [9], atopic dermatitis [10] and eczema [11], as well as other allergy-related pathologies. In addition, genome-wide association studies have found single nucleotide polymorphism (SNPs) in TSLP to be associated with asthma [12], allergic rhinitis $[13,14]$ and eosinophilic esophagitis in children [15].

Given the importance of TSLP in these inflammatory diseases and its role as a key cytokine in the initiation of inflammatory disease, we hypothesized that genetic variants in this gene and those encoding its receptor subunits could be implicated in NIUA susceptibility. Therefore, in this study we assessed the association of common SNPs in TSLP, TSLPR and IL7R with NIUA.

\section{Materials and Methods}

\section{Study Population}

This study was performed using a case-control design and included unrelated individuals of Spanish descent: 377 NIUA patients and 585 controls. All participants signed an informed consent and the protocols were approved by the institutional ethics committee (Comité Coordinador de Ética de la Investigación Biomédica de Andalucía), following the ethical principles declared in the Declaration of Helsinki.

NIUA patients (cases) were diagnosed by clinical history, having presented more than two hypersensitivity reactions (urticaria and/or angioedema) to at least two different NSAIDs, and had no history of chronic urticaria [16]. Patients who had suffered less than three episodes were subjected to an oral provocation test (OPT) with aspirin to confirm diagnosis [17]. A detailed clinical algorithm, combining OPT and clinical history for patient diagnosis, has been described previously [16-18]. The control group consisted of individuals with no previous history of HDRs and with a negative OPT to NSAIDs. All participants were recruited by the
Table 1. Clinical characteristics and reaction-provoking drugs for the study subjects

\begin{tabular}{|c|c|c|c|}
\hline & $\begin{array}{l}\text { Control } \\
\text { group }\end{array}$ & $\begin{array}{l}\text { NIUA } \\
\text { group }\end{array}$ & $\mathrm{p}$ value \\
\hline $\mathrm{n}$ & 580 & 369 & \\
\hline Mean age $( \pm S D)$, years & $36 \pm 15$ & $37 \pm 16$ & 0.225 \\
\hline Female, \% & 63.3 & 58.9 & 0.269 \\
\hline Atopy, \% & 43.2 & 63.3 & $<0.0001$ \\
\hline \multicolumn{4}{|l|}{ Causative drugs, $\%$} \\
\hline Propionic acid derivatives & n.a. & 35.3 & n.a. \\
\hline Acetyl salicylic acid & n.a. & 23.2 & n.a. \\
\hline Metamizole & n.a. & 17.1 & n.a. \\
\hline Paracetamol & n.a. & 9.6 & n.a. \\
\hline Other NSAIDs & n.a. & 14.8 & n.a. \\
\hline
\end{tabular}

allergy services of two hospitals belonging to the RIRAAF (Spanish National Network for Drug Allergy).

The atopic status was determined by skin prick test (SPT) for cases and controls. SPT was performed with a set of common inhalant allergens, including pollens, house dust mites, molds and animal danders (ALK, Madrid, Spain). A positive SPT was defined as a weal diameter at least $3 \mathrm{~mm}$ larger than the negative control to at least one allergen. The patients were requested to stop taking any antihistamine-containing medications at least 10 days before testing. An individual was considered atopic if he/she showed a positive SPT. The clinical and demographic characteristics of the study subjects and culprit drugs are shown in table 1.

\section{Selection of SNPS}

Tag SNPs, informative of other common genetic variations in the TLSP, IL7R and TSLPR genes, were selected using Haploview based on information from the HapMap II database [19], including $10 \mathrm{~kb}$ of flanking regions for each gene and using variants with a minor allele frequency $(\mathrm{MAF}) \geq 0.10$ and an $\mathrm{r}^{2} \geq 0.8[10,20]$.

\section{Genotyping}

Genomic DNA was extracted from peripheral white blood cells using the FlexiGene DNA kit (Qiagen, Hilden, Germany) following the manufacturer's protocol. Sample quantification was performed using Quant-iT PicoGreen dsDNA reagents (Invitrogen, Waltham, Mass., USA).

Genotyping was carried out using TaqManG probes for each selected SNP. Custom assays were used to genotype rs1494565 in $I L 7 R$ and the three TSLPR SNPs; table 2 describes the sequence utilized for designing these custom assays. For the remaining SNPs, assay serial numbers as provided by the manufacturer are given in table 2. Genotyping and allelic discrimination was performed using the 7500 Fast Real-Time PCR System (Life Technologies, Carlsbad, Calif., USA).

\section{Statistical Analysis}

Clinical and demographical data were analyzed using $\mathrm{R}$ program version 3.1.2 by $\chi^{2}$ test and the Mann-Whitney U test. Qual- 
Table 2. Details of the primers/serial numbers, alleles and quality control measures for the genotyped SNPs for TSLP, IL7R and TSLPR

\begin{tabular}{|c|c|c|c|c|c|}
\hline Gene & SNPs & Alleles & Assay & CR & $\begin{array}{l}\text { HWE } \\
\text { p value } \\
\text { (control } \\
\text { subjects) }\end{array}$ \\
\hline \multirow[t]{6}{*}{ TSLP } & rs1545169 & $\mathrm{T}>\mathrm{G}$ & C_7569762_10 & 98.1 & 0.009 \\
\hline & rs764917 & $\mathrm{C}>\mathrm{A}$ & C_3166717_10 & 97.0 & 0.502 \\
\hline & rs1837253 & $\mathrm{C}>\mathrm{T}$ & C_11910823_20 & 99.0 & 0.717 \\
\hline & rs3806932 & $\mathrm{A}>\mathrm{G}$ & C_3166721_10 & 99.3 & 0.189 \\
\hline & rs2289276 & $\mathrm{C}>\mathrm{T}$ & C_3166723_20 & 99.8 & 0.404 \\
\hline & rs897801 & $\mathrm{T}>\mathrm{C}$ & C_7569747_10 & 98.0 & 0.060 \\
\hline \multirow[t]{6}{*}{$I L 7 R$} & rs $1494565^{\mathrm{a}}$ & $\mathrm{A}>\mathrm{C}$ & CustSeq1 & 99.7 & 0.931 \\
\hline & rs11567714 & $\mathrm{C}>\mathrm{T}$ & C_31636860_10 & 99.4 & 0.550 \\
\hline & rs6897932 & $\mathrm{C}>\mathrm{T}$ & C_2025977_10 & 99.4 & 0.656 \\
\hline & rs13167136 & $\mathrm{G}>\mathrm{A}$ & C_3 31636668 _10 & 99.4 & 0.741 \\
\hline & rs700179 & $A>G$ & C_8811847_10 & 98.8 & 0.920 \\
\hline & rs10058453 & $\mathrm{T}>\mathrm{C}$ & C_3281158_10 & 99.1 & 0.094 \\
\hline \multirow[t]{3}{*}{ TSLPR } & rs36139698 & $\mathrm{G}>\mathrm{A}$ & CustSeq2 & 89.4 & 0.313 \\
\hline & rs $36177645^{a}$ & $\mathrm{~T}>\mathrm{C}$ & CustSeq3 & 88.5 & 0.579 \\
\hline & $\mathrm{rs} 36133495^{\mathrm{a}}$ & $\mathrm{A}>\mathrm{G}$ & CustSeq4 & 85.0 & 0.841 \\
\hline
\end{tabular}

${ }^{a}$ Custom assays designed by the manufacturer on the basis of sequences: CustSeq1, GTTGCTGGCCCCAACCATGTTCCTGATTGCCTAGGAAATA[A/C]AGCCCTTGAAATATGACATCTGCATCTGGATAGATGAATG; CustSeq2, CGGCTTCAGTCTTGGCCAACTGGACTACCAGGGGCTCCTC[A/G]GGGCCACTTTCTTGCTCTGCACCTGCCATCTTGTGGAGGT; CustSeq3, GCATCCTGGGAGACTCGGCTTCAGTCTTGGCCA A C T G G A C [ C / T ] A C C A G G G G C T C C T C G G G G C CACTTTCTTGCTCTGCACCTG. CustSeq4: TCATCACAAAGGTGAAGCCCCCGATTGTGACCACATCACC[A/G]CCTTGGAGGGGCTGGTGGGGAAGCTGGAGGGATCCCCCAG.

ity control was performed using PLINK [21] to discard SNPs with a completion rate $(\mathrm{CR})<90 \%, \mathrm{MAF}<0.05$ and deviation from Hardy-Weinberg equilibrium (HWE) with $\mathrm{p}<0.0033$ (i.e. a Bonferroni correction; corresponding to a threshold calculated by dividing the nominal threshold of 0.05 for a single test by the total number of SNPs tested). Samples with a CR $<80 \%$ were discarded.

To perform the imputation of additional variants in our candidate genes, we downloaded the 1,000 Genomes Project Phase 3 data [22] and used VCFtools to extract the variants from the regions of interest [23]. PLINK was then used to extract the data from the 503 European individuals included in the dataset. Imputation was carried out with Mach software (version 1.0.16) [24]. Association testing was performed with Mach2dat, which uses logistic regression based on the inferred allele count (allele dosage) [25]. SNPs with MAF $<0.10$ and RSQR $<0.3$ were removed from further analyses. RSQR is an imputation quality measure, defined as the correlation $\left(\mathrm{r}^{2}\right)$ between genotyped and imputed SNP values. Data were presented as regional plots using Locus Zoom [26]. A false discovery rate (FDR) was computed using q value for R [27], and an FDR $\leq 5 \%$ was considered significant.
Statistical power was calculated using Quanto (http://biostats. usc.edu/software) taking into account the number of independent SNPs for each gene as estimated with SNPSpD (https://genepi. qimr.edu.au/). The statistical power for two-tailed associations was $81.89 \%$ for risk alleles with MAF $=0.4$.

\section{Results}

Five control and 8 case subjects did not pass quality control due to a genotype CR below $80 \%$, leaving the study with 580 control subjects and 369 NIUA patients for further analyses. No significant differences for age and sex were found between the two groups (table 1). Statistically significant differences were found between NIUA patients and the controls for atopic status $(\mathrm{p}<0.0001)$. The main culprit drugs were propionic acid derivatives (35.3\%) followed by aspirin (23.2\%; table 1$)$.

A total of 15 SNPs were genotyped (table 2). All SNPs had an MAF $>0.10$ in controls and a p value greater than $0.0033(0.05 / 15)$ for HWE. TSLP and IL7R SNPs had a CR $>90 \%$, whereas SNPs in TSLPR (rs36139698, rs36177645, rs36133495) showed a CR $<90 \%$ and were therefore excluded from further analyses.

After imputation and quality control filters, a total of 29 TSLP variants and $110 I L 7 R$ variants were analyzed for association studies (online suppl. tables S1 and S2; see www.karger.com/doi/10.1159/000444797 for all online suppl. material). Out of the 139 SNPs tested, none of the variants in $I L 7 R$ showed a significant association with NIUA (online suppl. table S2), and only two SNPs in TSLP (rs1816678 and rs764917) showed a nominal association with NIUA ( $\mathrm{p}=0.033$ and 0.024 , respectively; table 3; online suppl. fig. S1). These associations suggested a protective effect for the rs1816678-G allele (odds ratio $=0.76)$ and rs764917-A allele (odds ratio $=0.81$ ). However, neither of these results were significant following FDR correction (FDR $=31.5 \%$ for both). No association was found between any of the common SNPs analyzed here and atopy, either before or after applying a multiple testing correction.

\section{Discussion}

In this study we assessed the association between genetic variants in TSLP, IL7R and TSLPR, and NIUA. TSLP could act through mast cell activation to stimulate the release of Th2 cytokines, which are implicated in the regulation of the arachidonic acid pathway [28, 29]. Another 
Table 3. Imputation and association results for SNPs nominally associated with NIUA

\begin{tabular}{lllllllll}
\hline Gene & rs & $\begin{array}{l}\text { Allele 1/ } \\
\text { allele 2 }\end{array}$ & FREQ1 & RSQR & OR & 95\% CI & p value & FDR \\
\hline TSLP & rs1816678 & G/A & 0.598 & 0.58 & 0.76 & $0.594-0.978$ & 0.033 & 31.5 \\
TSLP & rs764917 & A/C & 0.540 & 0.98 & 0.81 & $0.666-0.971$ & 0.024 & 31.5 \\
\hline
\end{tabular}

FREQ1 = Frequency of allele $1 ;$ RSQR = an imputation quality measure which estimates the correlation $\left(\mathrm{r}^{2}\right)$ between imputed and true genotypes; $\mathrm{OR}=$ odds ratio; $\mathrm{FDR}=\mathrm{p}$ value after false discovery rate correction.

potential mechanism of action could be through the TSLP-activated pSTAT5 pathway leading to FCER $1 G$ demethylation and FceRI overexpression [30]; this mechanism could have a role in NSAID hypersensitivity, perhaps in conjunction with variation in the $\operatorname{IgE}$ receptor genes, which have been shown to be associated with this pathology, although results are mixed [31-34].

TSLP polymorphisms have been studied in the context of respiratory [12-14, 35-37] and cutaneous diseases [10-11], including NERD [9]. However, in this study only two imputed SNPs showed a nominal genetic association (rs1816678 and rs764917) with NIUA, suggesting a potential role of TSLP in NIUA, although this must be confirmed.

The SNP rs 1816678 is located $9.6 \mathrm{~kb}$ upstream of TSLP. This polymorphism has been predicted to alter the lipidactivated nuclear receptor (LXR) and Sp4 transcription factor regulatory motifs [38]. By affecting LXR regulation, this SNP may alter lipid homeostasis and inflammation [39], whilst changes in Sp4 activity may have a role in neuroinflammation [40]. Nevertheless, the potential role of this SNP in NIUA needs further study.

The second SNP, rs764917, is located in an intergenic region $5.3 \mathrm{~kb} 5^{\prime}$ of TSLP. It has been proposed to influence transcriptional regulatory mechanisms [36]. In fact, this SNP is predicted to alter five regulatory motifs for $\mathrm{BarH}$ like homeobox 1 (Barhl1), cycling T2 (CCNT2), GATA binding protein (GATA), histone deacetylase 2 (HDAC2) and H6 family homeobox $2(\mathrm{Hmx}-2)$ [38], which could affect TSLP regulation. Barhll is a transcriptional regulator [41] and CCNT2 is a subunit of the transcription elongation factor $(\mathrm{TEFb})$ that it is part of the RNA polymerase II [42]. Barhl1, CCNT2 and Hmx-2 have not previously been associated with NIUA or allergic diseases; however, GATA is a superfamily of transcription factors implicated in the regulation of cellular differentiation of important immune cells, such as basophils [43] and eosinophils [44]. Specifically, GATA-3 is implicated in the development of
Th2 responses in allergic dermatitis $[45,46]$ and in selective, single NSAID-induced urticaria/angioedema [47]. Furthermore, it has been suggested that GATA-3 blockage by corticosteroids could be used as a treatment for allergies due to the inhibition of the Th2 response [48]. More studies are needed to explore whether rs764917 may affect GATA regulation of TSLP. HDAC2 is a member of a transcriptional repressor complex involved in transcriptional regulation, cell cycle progression and development, and may have a role in asthma [49-51], allergic disease [51] and COPD [52]. Moreover, an inhibitor of HDAC2 has been shown to be effective in preventing nasal polyposis [53]. In a previous genetic association study, a CC genotype at rs764917 was shown to have a protective effect for patients with chronic rhinosinusitis and nasal polyps [36]. Interestingly, in our study we found the A allele to be protective. To date, the relationship between changes in binding of HDAC2 due to rs764917 in HDRs to NSAIDs has not been analyzed.

Both IL7R and TSLPR have been shown to be important for TSLP signaling and functioning during the inflammatory response [54]. However, although several SNPs in $I L 7 R$ have been associated with cutaneous diseases like atopic dermatitis [10] and lupus erythematosus [55], we did not find any association with NIUA.

NSAIDs are highly prescribed for the treatment of pain, fever and inflammation, with more than ten million individuals using these drugs daily [56]. However, they are the main cause of HDRs [57], including anaphylaxis reactions [58]. NIUA is the most frequent entity in NSAID HDRs; nevertheless, genetic association studies for this pathology are scarce $[2,17,59-63]$ and have not previously analyzed the role of TSLP and its receptor in this clinical entity. Although there is still some controversy, it has been shown that aspirin-exacerbated cutaneous disease is a different subphenotype of chronic spontaneous urticaria [64], representing a different entity to NIUA, which occurs in individuals without a history of underlying chronic urticaria 
[65]. Therefore, we compared NIUA patients to normal healthy controls and did not include NSAID-tolerant chronic spontaneous urticaria patients as a control. This approach has been used in previous genetic association studies of NIUA patients carried out by our group [62].

In conclusion, we did not find any significant associations for common SNPs in the studied genes in a Spanish population of NIUA patients compared to healthy controls. However, we believe the suggestive association found for two TSLP SNPs warrants further study.

\section{Acknowledgments}

We thank Mrs. Luisa Galindo Reyes for her participation in sample collection. This study was supported by grants from the Carlos III National Health Institute (Spanish Ministry of Economy and Competitiveness) RD12/0013 (RIRAAF Network), FIS PI12/02247 and FIS PI13/02598. It also received support from the Andalusian Public Health Service (PI-0279-2012 and PI-04632013). M.d.C.P.-S. is a researcher from the researcher training program (Ref. FI11/00117), J.A.C.-G. is from the Miguel Servet Program (Ref. CP14/00034) and J.R.P. is from the Sara Borrell Program (Ref. CD14/00242; Carlos III National Health Institute).

\section{References}

1 Dona I, Blanca-Lopez N, Cornejo-Garcia J: NSAIDs are the most frequent medicaments involved in hypersensitivity drug reactions. Eur Ann Allergy Clin Immunol 2014;46:63.

2 Cornejo-García JA, Jagemann LR, BlancaLópez N, Doña I, Flores C, Guéant-Rodríguez RM, et al: Genetic variants of the arachidonic acid pathway in non-steroidal antiinflammatory drug-induced acute urticaria. Clin Exp Allergy 2012;42:1772-1781.

3 Park SM, Park JS, Park HS, Park CS: Unraveling the genetic basis of aspirin hypersensitivity in asthma beyond arachidonate pathways. Allergy Asthma Immunol Res 2013;5: 258-276.

4 Losol P, Yoo HS, Park HS: Molecular genetic mechanisms of chronic urticaria. Allergy Asthma Immunol Res 2014;6:13-21.

5 Liu YJ: Thymic stromal lymphopoietin: master switch for allergic inflammation. J Exp Med 2006;203:269-273.

6 Ziegler SF, Liu YJ: Thymic stromal lymphopoietin in normal and pathogenic $\mathrm{T}$ cell development and function. Nat Immunol 2006; 7:709-714.

7 Soumelis V, Reche PA, Kanzler H, Yuan W, Edward G, Homey B, Gilliet M, Ho S, Antonenko S, Lauerma A, Smith K, Gorman D, Zurawski S, Abrams J, Menon S, McClanahan T, de Waal-Malefyt R, Bazan F, Kastelein RA, Liu YJ: Human epithelial cells trigger dendritic cell mediated allergic inflammation by producing TSLP. Nat Immunol 2002; 3:673-680.

8 Kay AB, Clark P, Maurer M, Ying S: Elevations in T-helper-2-initiating cytokines (interleukin-33, interleukin-25 and thymic stromal lymphopoietin) in lesional skin from chronic spontaneous ('idiopathic') urticaria. Br J Dermatol 2015;172:1294-1302.

9 Kurosawa M, Yukawa T, Hozawa S, Sutoh E: Single nucleotide polymorphisms in thymic stromal lymphopoietin gene are not associated with aspirin-exacerbated respiratory disease susceptibility - a pilot study in a Japanese population. J Allergy Ther 2015;6: 214.
10 Gao PS, Rafaels NM, Mu D, Hand T, Murray $\mathrm{T}$, Boguniewicz M, Hata T, Schneider L, Hanifin JM, Gallo RL, Gao L, Beaty TH, Beck LA, Leung DY, Barnes KC: Genetic variants in thymic stromal lymphopoietin are associated with atopic dermatitis and eczema herpeticum. J Allergy Clin Immunol 2010;125: 1403-1407.

11 Miyake Y, Hitsumoto S, Tanaka K, Arakawa M: Association between TSLP polymorphisms and eczema in Japanese women: the Kyushu Okinawa Maternal and Child Health study. Inflammation 2015;38:1663-1668.

12 Hirota T, Takahashi A, Kubo M, Tsunoda T, Tomita K, Doi S, Fujita K, Miyatake A, Enomoto T, Miyagawa T, Adachi M, Tanaka H, Niimi A, Matsumoto $\mathrm{H}$, Ito I, Masuko $\mathrm{H}$, Sakamoto T, Hizawa N, Taniguchi M, Lima JJ, Irvin CG, Peters SP, Himes BE, Litonjua AA, Tantisira KG, Weiss ST, Kamatani N, Nakamura Y, Tamari M: Genome-wide association study identifies three new susceptibility loci for adult asthma in the Japanese population. Nat Genet 2011;43:893-896.

13 Torgerson DG, Ampleford EJ, Chiu GY, Gauderman WJ, Gignoux CR, Graves PE, et al: Meta-analysis of genome-wide association studies of asthma in ethnically diverse North American populations. Nat Genet 2011;43:887-892.

14 Nilsson D, Henmyr V, Hallden C, Sall T, Kull I, Wickman M, Melen E, Cardell LO: Replication of genome-wide associations with allergic sensitization and allergic rhinitis. Allergy 2014;69:1506-1514.

15 Rothenberg ME, Spergel JM, Sherrill JD, Annaiah K, Martin LJ, Cianferoni A, Gober L, Kim C, Glessner J, Frackelton E, Thomas K, Blanchard C, Liacouras C, Verma R, Aceves S, Collins MH, Brown-Whitehorn T, Putnam PE, Franciosi JP, Chiavacci RM, Grant SF, Abonia JP, Sleiman PM, Hakonarson $\mathrm{H}$ : Common variants at $5 \mathrm{q} 22$ associate with pediatric eosinophilic esophagitis. Nat Genet 2010;42:289-291.
16 Ortega N, Dona I, Moreno E, Audicana MT Barasona MJ, Berges-Gimeno MP, BlancaLopez N, Lobera T, Padial A, Rosado A, Torres MJ: Practical guidelines for diagnosing hypersensitivity reactions to nonsteroidal anti-inflammatory drugs. J Investig Allergol Clin Immunol 2014;24:308-323.

17 Bellia A, Garcovich C, D'Adamo M, Lombardo M, Tesauro M, Donadel G, Gentileschi P, Lauro D, Federici M, Lauro R, Sbraccia P: Serum 25-hydroxyvitamin D levels are inversely associated with systemic inflammation in severe obese subjects. Intern Emerg Med 2013;8:33-40.

18 Kowalski ML, Makowska JS: Seven steps to the diagnosis of NSAIDs hypersensitivity: how to apply a new classification in real practice? Allergy Asthma Immunol Res 2015;7: 312-320.

19 Frazer KA, Ballinger DG, Cox DR, Hinds DA, Stuve LL, Gibbs RA, et al: A second generation human haplotype map of over 3.1 million SNPs. Nature 2007;449:851-861.

20 Sherrill JD, Gao PS, Stucke EM, Blanchard C, Collins MH, Putnam PE, Franciosi JP, Kushner JP, Abonia JP, Assa'ad AH, Kovacic MB, Biagini Myers JM, Bochner BS, He H, Hershey GK, Martin LJ, Rothenberg ME: Variants of thymic stromal lymphopoietin and its receptor associate with eosinophilic esophagitis. J Allergy Clin Immunol 2010;126:160-165.

21 Purcell S, Neale B, Todd-Brown K, Thomas L, Ferreira MA, Bender D, Maller J, Sklar P, de Bakker PI, Daly MJ, Sham PC: PLINK: a tool set for whole-genome association and population-based linkage analyses. Am J Hum Genet 2007;81:559-575.

22 Abecasis GR, Altshuler D, Auton A, Brooks LD, Durbin RM, Gibbs RA, Hurles ME, McVean GA: A map of human genome variation from population-scale sequencing. $\mathrm{Na}$ ture 2010;467:1061-1073.

23 Danecek P, Auton A, Abecasis G, Albers CA, Banks E, DePristo MA, Handsaker RE, Lunter G, Marth GT, Sherry ST, McVean G, Durbin $\mathrm{R}$ : The variant call format and VCFtools. Bioinformatics 2011;27:2156-2158. 
24 Li Y, Willer CJ, Ding J, Scheet P, Abecasis GR: $\mathrm{MaCH}$ : using sequence and genotype data to estimate haplotypes and unobserved genotypes. Genet Epidemiol 2010;34:816834.

25 Marchini J, Howie B: Genotype imputation for genome-wide association studies. Nat Rev Genet 2010;11:499-511.

26 Pruim RJ, Welch RP, Sanna S, Teslovich TM, Chines PS, Gliedt TP, Boehnke M, Abecasis GR, Willer CJ: LocusZoom: regional visualization of genome-wide association scan results. Bioinformatics 2010;26:2336-2337.

27 Storey JD, Tibshirani R: Statistical significance for genome-wide studies. Proc Natl Acad Sci USA 2003;100:9440-9445.

28 Varga EM, Jacobson MR, Masuyama K, Rak S, Till SJ, Darby Y, Hamid Q, Lund V, Scadding GK, Durham SR: Inflammatory cell populations and cytokine mRNA expression in the nasal mucosa in aspirin-sensitive rhinitis. Eur Respir J 1999;14:610-615.

29 Steinke JW, Payne SC, Borish L: Interleukin-4 in the generation of the AERD phenotype: implications for molecular mechanisms driving therapeutic benefit of aspirin desensitization. J Allergy (Cairo) 2012;2012: 182090.

30 Liang Y, Chang C, Lu Q: The genetics and epigenetics of atopic dermatitis-filaggrin and other polymorphisms. Clin Rev Allergy Immunol 2015, Epub ahead of print.

31 Potaczek DP, Sanak M, Mastalerz L, Setkowicz M, Kaczor M, Nizankowska E, Szczeklik A: The alpha-chain of high-affinity receptor for IgE (FceRIa) gene polymorphisms and serum IgE levels. Allergy 2006;61:12301233.

32 Potaczek DP, Nishiyama C, Sanak M, Szczeklik A, Okumura K: Genetic variability of the high-affinity IgE receptor alpha-subunit (FceRIa). Immunol Res 2009;45:75-84.

33 Bae JS, Kim SH, Ye YM, Yoon HJ, Suh CH, Nahm DH, Park HS: Significant association of FceRIa promoter polymorphisms with aspirin-intolerant chronic urticaria. J Allergy Clin Immunol 2007;119:449-456.

34 Palikhe NS, Kim SH, Cho BY, Ye YM, Hur GY, Park HS: Association of three sets of high-affinity IgE receptor (FceR1) polymorphisms with aspirin-intolerant asthma. Respir Med 2008;102:1132-1139.

35 He JQ, Hallstrand TS, Knight D, ChanYeung M, Sandford A, Tripp B, Zamar D, Bosse Y, Kozyrskyj AL, James A, Laprise C, Daley D: A thymic stromal lymphopoietin gene variant is associated with asthma and airway hyperresponsiveness. J Allergy Clin Immunol 2009;124:222-229.

36 Zhang $\mathrm{Y}$, Wang X, Zhang W, Han D, Zhang L, Bachert C: Polymorphisms in thymic stromal lymphopoietin gene demonstrate a gender and nasal polyposis-dependent association with chronic rhinosinusitis. Hum Immunol 2013;74:241-248.
37 Bunyavanich S, Melen E, Wilk JB, Granada M, Soto-Quiros ME, Avila L, Lasky-Su J, Hunninghake GM, Wickman M, Pershagen G, O'Connor GT, Weiss ST, Celedon JC: Thymic stromal lymphopoietin (TSLP) is associated with allergic rhinitis in children with asthma. Clin Mol Allergy 2011;9:1.

38 Ward LD, Kellis M: HaploReg: a resource for exploring chromatin states, conservation, and regulatory motif alterations within sets of genetically linked variants. Nucleic Acids Res 2012;40:D930-D934.

39 Kiss M, Czimmerer Z, Nagy L: The role of lipid-activated nuclear receptors in shaping macrophage and dendritic cell function: from physiology to pathology. J Allergy Clin Immunol 2013;132:264-286.

40 Mao XR, Moerman-Herzog AM, Chen Y, Barger SW: Unique aspects of transcriptional regulation in neurons - nuances in $\mathrm{NFKB}$ and Sp1-related factors. J Neuroinflammation 2009;6:16.

41 Ravasi T, Suzuki H, Cannistraci CV, Katayama S, Bajic VB, Tan K, et al: An atlas of combinatorial transcriptional regulation in mouse and man. Cell 2010;140:744-752.

42 Kurosu T, Zhang F, Peterlin BM: Transcriptional activity and substrate recognition of cyclin T2 from P-TEFb. Gene 2004;343:173179.

43 Mouthon MA, Bernard O, Mitjavila MT, Romeo PH, Vainchenker W, Mathieu-Mahul D: Expression of tal-1 and GATA-binding proteins during human hematopoiesis. Blood 1993;81:647-655.

44 Zon LI, Yamaguchi Y, Yee K, Albee EA, Kimura A, Bennett JC, Orkin SH, Ackerman SJ: Expression of mRNA for the GATAbinding proteins in human eosinophils and basophils: potential role in gene transcription. Blood 1993;81:3234-3241.

45 Tamauchi $\mathrm{H}$, Amoh Y, Itoh M, Terashima M, Masuzawa M, Habu S, Katsuoka K, Iwabuchi K: GATA-3 regulates contact hyperresponsiveness in a murine model of allergic dermatitis. Immunobiology 2012;217:446454.

46 Bae CJ, Lee JW, Shim SB, Jee SW, Lee SH, Woo JM, Lee CK, Hwang DY: GATA binding protein 3 overexpression and suppression significantly contribute to the regulation of allergic skin inflammation. Int J Mol Med 2011;28:171-179.

47 Cornejo-Garcia JA, Fernandez TD, Torres MJ, Carballo M, Hernan I, Antunez C, Blanca M, Mayorga C: Differential cytokine and transcription factor expression in patients with allergic reactions to drugs. Allergy 2007; 62:1429-1438.

48 Maneechotesuwan K, Yao X, Ito K, Jazrawi E, Usmani OS, Adcock IM, Barnes PJ: Suppression of GATA-3 nuclear import and phosphorylation: a novel mechanism of corticosteroid action in allergic disease. PLoS Med 2009;6:e1000076.
49 Adcock IM, Tsaprouni L, Bhavsar P, Ito K: Epigenetic regulation of airway inflammation. Curr Opin Immunol 2007;19:694-700.

50 Kobayashi Y, Bossley C, Gupta A, Akashi K, Tsartsali L, Mercado N, Barnes PJ, Bush A, Ito K: Passive smoking impairs histone deacetylase- 2 in children with severe asthma. Chest 2014;145:305-312.

51 Bhavsar P, Ahmad T, Adcock IM: The role of histone deacetylases in asthma and allergic diseases. J Allergy Clin Immunol 2008;121: 580-584.

52 Sohal SS, Reid D, Soltani A, Weston S, Muller HK, Wood-Baker R, Walters EH: Changes in airway histone deacetylase 2 in smokers and COPD with inhaled corticosteroids: a randomized controlled trial. PLoS One 2013; 8:e64833.

53 Cho JS, Moon YM, Park IH, Um JY, Kang JH, Kim TH, Lee SH, Kang HJ, Lee HM: Effects of histone deacetylase inhibitor on extracellular matrix production in human nasal polyp organ cultures. Am J Rhinol Allergy 2013;27:18-23.

54 Park LS, Martin U, Garka K, Gliniak B, Di Santo JP, Muller W, Largaespada DA, Copeland NG, Jenkins NA, Farr AG, Ziegler SF, Morrissey PJ, Paxton R, Sims JE: Cloning of the murine thymic stromal lymphopoietin (TSLP) receptor: formation of a functional heteromeric complex requires interleukin 7 receptor. J Exp Med 2000;192:659-670.

55 Wang XS, Wen PF, Zhang M, Hu LF, Ni J, Qiu LJ, Liang Y, Zhao W, Huang Q, Tao SS, $\mathrm{Xu} W D$, Feng CC, Cen H, Leng RX, Pan HF, Ye DQ: Interleukin-7 receptor single nucleotide polymorphism rs6897932 (C/T) and the susceptibility to systemic lupus erythematosus. Inflammation 2014;37:615-620.

56 Abramson SB: Clinical guidelines: expert recommendations for NSAID use: a userfriendly model? Nat Rev Rheumatol 2011;7: 133-134.

57 Dona I, Barrionuevo E, Blanca-Lopez N, Torres MJ, Fernandez TD, Mayorga C, Canto G, Blanca M: Trends in hypersensitivity drug reactions: more drugs, more response patterns, more heterogeneity. J Investig Allergol Clin Immunol 2014;24:143-153.

58 Ye YM, Kim MK, Kang HR, Kim TB, Sohn SW, Koh YI, Park HK, Jang GC, Kim CW, Jee YK, Hur GY, Kim JH, Kim SH, Choi GS, Lee SK, Park HS: Predictors of the severity and serious outcomes of anaphylaxis in Korean adults: a multicenter retrospective case study. Allergy Asthma Immunol Res 2015;7: 22-29.

59 Kim SH, Sanak M, Park HS: Genetics of hypersensitivity to aspirin and nonsteroidal anti-inflammatory drugs. Immunol Allergy Clin North Am 2013;33:177-194. 
60 Agundez JA, Ayuso P, Cornejo-Garcia JA, Blanca M, Torres MJ, Dona I, Salas M, Blanca-Lopez N, Canto G, Rondon C, Campo P, Laguna JJ, Fernandez J, Martinez C, GarciaMartin E: The diamine oxidase gene is associated with hypersensitivity response to nonsteroidal anti-inflammatory drugs. PLoS One 2012; 7:e47571.

61 Ayuso P, Blanca M, Cornejo-Garcia JA, Torres MJ, Dona I, Salas M, Blanca-Lopez N, Canto G, Rondon C, Campo P, Laguna JJ, Fernandez J, Martinez C, Agundez JA, Garcia-Martin E: Variability in histamine receptor genes HRH1, HRH2 and HRH4 in patients with hypersensitivity to NSAIDs. Pharmacogenomics 2013;14:1871-1878.
62 Cornejo-Garcia JA, Flores C, Plaza-Seron MC, Acosta-Herrera M, Blanca-Lopez N, Dona I, Torres MJ, Mayorga C, GueantRodriguez RM, Ayuso P, Fernandez J, Laguna JJ, Agundez JA, Garcia-Martin E, Gueant JL, Canto G, Blanca M: Variants of CEP68 gene are associated with acute urticaria/angioedema induced by multiple non-steroidal anti-inflammatory drugs. PLoS One 2014; 9:e90966.

63 Cornejo-Garcia JA, Liou LB, Blanca-Lopez N, Dona I, Chen CH, Chou YC, Chuang HP, Wu JY, Chen YT, Plaza-Seron Mdel C, Mayorga C, Gueant-Rodriguez RM, Lin SC, Torres MJ, Campo P, Rondon C, Laguna JJ, Fernandez J, Gueant JL, Canto G, Blanca M, Lee
MT: Genome-wide association study in NSAID-induced acute urticaria/angioedema in Spanish and Han Chinese populations. Pharmacogenomics 2013;14:1857-1869.

64 Sanchez-Borges M, Caballero-Fonseca F, Capriles-Hulett A, Gonzalez-Aveledo L: Aspirin-exacerbated cutaneous disease (AECD) is a distinct subphenotype of chronic spontaneous urticaria. J Eur Acad Dermatol Venereol 2015;29:698-701.

65 Dona I, Blanca-Lopez N, Torres MJ, Gomez F, Fernandez J, Zambonino MA, Monteseirin FJ, Canto G, Blanca M, Cornejo-Garcia JA: NSAID-induced urticaria/angioedema does not evolve into chronic urticaria: a 12-year follow-up study. Allergy 2014;69:438-444. 